UDC 338.439.5:636.4.022

JEL Classification: D47, L22, 012

DOI: 10.15587/2706-5448.2021.230422

Article type «Reports on Research Projects»

\section{Olena Shust, Igor Paska, Dmytro Krysanov, Marat Ibatullin, Iryna Artimonova}

\title{
A5SESSMENT OF PIG PRODUCTS MARKET INFRASTRUCTURE FORMATION
}

The object of research is the functioning of the subjects of infrastructural support for the functioning of the market for pig products, in particular, its information and transport components. Now one of the main problems in ensuring the food and biological safety of any country, which must be solved in the near future, is the formation of a traceability system for all livestock products, which will provide a positive effect at the entire stage of commodity circulation. Experience shows that the complexity and high level of costs associated with running an animal transport business are holding back the quantitative growth of companies in this market segment. Therefore, the work is devoted to the substantiation and improvement of the theoretical and methodological foundations, as well as the development of practical recommendations for the formation and functioning of the infrastructure of the market for pig products.

The paper shows that the implementation of the proposed information system for traceability of the movement of pig products will ensure the quality of pig slaughter products, monitor compliance with the antiepizootic and antiepidemiological situation. An integrated approach to the segment of animal transportation will solve the main problems of organizing business, in particular: reducing transportation costs, minimizing environmental impact and ensuring humane treatment of animals. Methodological approaches to the formation of a monitoring system for the movement of products of animal origin based on the creation of an information system for automated document flow «Biosafety», which will ensure the traceability of the movement of pig products at all stages of the agri-food chain, have been substantiated. This will provide a qualitatively new level of information and communication technologies in the industry. In the course of the study, the comparison method was used to compare economic phenomena in different time periods in order to identify a causal relationship.

The information provided in the research process should become the basis for the development of measures to control the antiepizootic and antiepidemiological situation by local self-government bodies and the relevant specialized state bodies.

Keywords: traceability of the movement of pig products, transportation of animals, food and biological safety, regulatory support.

\section{How to cite}

Shust, O., Paska, I., Krysanov, D., Ibatullin, M., Artimonova, I. (2021). Assessment of pig products market infrastructure formation. Technology. Audit and Production Reserves, 2 (4 (58)), 28-32. doi: http://doi.org/10.15587/2706-5448.2021.230422

\section{Introduction}

The successful functioning of the pig market is largely determined by:

- the quality of interaction between the technical and organizational systems of procurement, transportation;

- the storage and sale of products;

- the activities of stock exchanges, wholesale structures, retail networks, a system of financial settlements between sellers and buyers, information and marketing services;

- the activities of other structures that provide direct communication in the system of exchange of commoditymoney relations between producers, consumers of goods and representatives of the market infrastructure - intermediaries [1].

Currently, most scientists pay attention to the study of the functioning of the subjects of the infrastructure of the market for pig products. Thus, the author of the work [2] paid considerable attention to the study of livestock markets as a component of the infrastructural support for the functioning of the livestock market. It should be noted that despite the lack of empirical data on the activities of trade and intermediary structures, their economic nature was revealed in the study [3]. Shpychak and Swynous, using the example of a questionnaire survey, showed the role and place of trade and intermediary structures in combining the interests of the producer and consumer 
of livestock products. Now one of the main problems in ensuring the country's food and biological security, which must be solved in the near future, is the formation of a traceability system for all livestock products, which will provide a positive effect at the entire stage of commodity circulation.

The traceability system is a strong anti-corruption tool for preventing illegal actions in the field of veterinary control and supervision will ensure the legality of the origin of raw materials and animal products. This circumstance requires detailed consideration, taking into account the experience of the leading countries of the world [4]. Experience shows that the complexity and high level of costs associated with running an animal transport business are holding back the quantitative growth of companies in this market segment. Significant investments are needed to change the situation. At the same time, an objective comprehensive assessment of their effectiveness is important, taking into account the peculiarities of animal transportation. In this regard, the development of the organizational and economic foundations of the subjects of infrastructural support for the functioning of the pig products market, in particular, its information and transport components, is urgent.

Thus, the object of research is the functioning of the subjects of infrastructural support for the functioning of the market for pig products, in particular, its information and transport components. And the aim of research is to assess the formation and functioning of the infrastructure of the market for pig products.

\section{Methods of research}

During the execution of the work, general scientific and special research methods were applied:

- monographic - when formulating the goal and object of research;

- comparison - to compare economic phenomena in different time periods in order to identify a causal relationship.

\section{Research results and discussion}

Today, the only means of verifying the legality of the origin of raw materials and products of animal origin is the analysis of accompanying documents that are issued by the relevant authorities of the state consumer service. However, its implementation is complicated by the inconsistency of the norms of the current legal acts regulating the movement of products of animal origin.

The main purpose of creating such an information system is to streamline the channels of product distribution. In particular, on the activities of the subjects of the market infrastructure of the market for pig products and the creation of an effective mechanism for preventing the appearance on it of products that are dangerous to the health of the final consumer of products. The software products «Argus», «Mercury» and «Vesta» have already been developed and registered as state information systems for ensuring biosafety. An analysis of their capabilities shows that with their help in real time it is possible to display and, accordingly, control the trade and transport flows of live farm animals and products of animal origin, including import and export operations [5]. It is also possible to form an information array of data on the results of research on the quality of slaughter products and the health status of farm animals by laboratories of the State Consumer Service of Ukraine. Based on the results of information on the quality of products, a quality certificate must be issued for each consignment of live animals or slaughter products; accompanying documents are also drawn up for the export of pigs outside the administrative region or country.

Considering the need to integrate Ukrainian legislation with European legislation, where similar biosafety control systems are in place, it is proposed to introduce an information system for quality control of animal products «Biosafety» on the territory of Ukraine (Fig. 1).

Information arrays should be formed on the basis of data that should be submitted:

- Agency for the identification of farm animals, in particular, their concentration, movement, etc.;

- district inspectors of veterinary medicine on the health status of animals entering for slaughter, mainly in households, the prevalence of diseases, the presence of burial sites, and the like;

- laboratories of veterinary medicine - the results of studies on the presence of diseases of farm animals and the like;

- laboratories of the sanitary and epidemiological service - the results of laboratory studies the presence of harmful microorganisms in the slaughter products of farm animals, the spread of which can worsen the epidemiological situation in a separate administrative region;

- veterinary service of livestock markets - information on the movement of farm animals by age and sex groups and species, by buying and selling them in livestock markets and on the state of animal health;

- veterinary service of certified slaughterhouses - on the volume of live cattle that go for slaughter, the administrative region and the subject of entrepreneurial activity, the nutritional status of animals, etc. [6].

All information is accumulated on the central server of the State Consumer Service, which is responsible for maintaining the quality of produced, processed and marketed products of animal origin. It is the basis for filling out quality certificates for slaughter products and accompanying documents for business entities to export it outside the administrative region and conduct exportimport operations.

Such information should become the basis for the development of measures to control the antiepizootic and antiepidemiological situation by local self-government bodies and the relevant specialized state bodies.

Let's believe that the absence of the proposed information system leads to:

- ineffectiveness of making managerial decisions on the containment of outbreaks of dangerous animal diseases, in particular, African swine fever (ASF);

- determination of the amount of damage incurred by agricultural producers;

- formation of financial reserves at the level of local communities and the state.

An effective system of commodity circulation of pig products from producer to end consumer is impossible without the presence of an important element of the market infrastructure - business entities that specialize in the transportation of live animals and slaughter products to the end consumer [7]. 


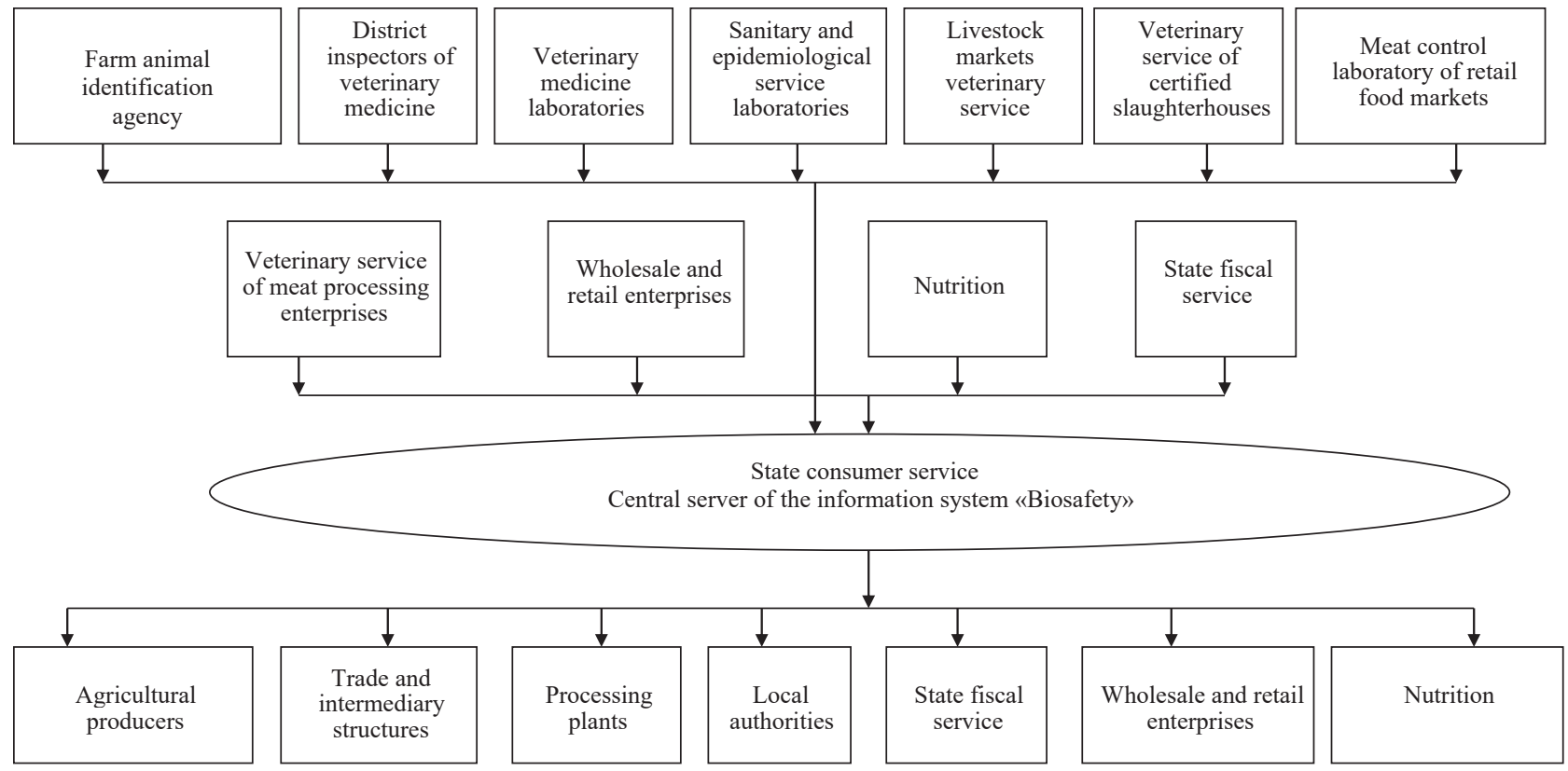

Fig. 1. Scheme of the functioning of «Biosafety» information system of pig products (developed by the author)

As the study showed, the market for the transportation of animals in the country is almost undeveloped in comparison with the leading countries [8]. The participating companies are in limited numbers, and their technical equipment is insufficient. Livestock that is purchased from households and small agricultural enterprises that transport vehicles that are not equipped for their transportation, which leads to a high probability of injury to animals. Also, slaughter products are transported unequipped with transport, leading to an increase in bacteriological contamination [9].

At the same time, the need for the transportation of animals in Ukraine and in international traffic is increasing, which is due to a number of reasons:

- import of livestock for fattening, further slaughter

of breeding animals;

- moving them within and between regions;

- increase in the number of domestic animals, also requires transport for their transportation [10].

The above factors reflect an increase in demand for this type of service and the prospects for doing this type of business. In this case, special attention should be paid to the conditions of transportation and care of animals during transportation.

The influence of market mechanisms, the qualitative and ethical aspects of the transportation performed, the conditions for ensuring competitiveness in the aggregate determine the compliance with certain requirements when organizing a business for the transportation of animals.

The system of requirements for the level of organization of animal transportation is summarized in Fig. 2.

According to this system of requirements, it is possible to compare different companies in terms of their competitiveness in this business segment. Moreover, to take into account not only the requirements that directly affect the level of profitability, but also the requirements are usually not taken into account, but have social significance, as well as an important social and environmental focus.

The top priority is economic requirements, according to which the company must profitably (break even) develop its activities. The investments required for the technical and technological improvement of the transportation process should pay off in the near future. At the same time, sources of investment can be both own and borrowed funds. To attract investors, it is important to ensure sufficient profitability and a low level of risk

The reduction of risks during transportation is facilitated by insurance, which makes it possible to compensate for losses in the event of an insured event and thereby create insurance coverage. Services for the formation of insurance risks for the time of transportation of animals can be performed both by the carriers themselves and by freight forwarding companies.

The most important condition for the development of a live animal transportation system is the availability of demand and the formation of a customer base. A business entity must assess the amount of demand, identify potential target customers and optimize the customer base in order to clearly understand with which customers and under what conditions it is profitable for it to work. Obviously, the existing client base will provide an opportunity to receive the necessary information, develop new types of services, new offers for clients.

To ensure the fulfillment of the considered economic requirements is intended to comply with the technical requirements, which stipulate that the company must have a modern specialized rolling stock. As well as loading and unloading equipment and devices with the help of which the loading and unloading of animals is carried out (loading and unloading platforms equipped with ramps, ramps or ladders).

Companies that provide services for the transport of farm animals must be provided with specialized transport and appropriate handling equipment.

Loading and unloading operations should be carried out taking into account the current regulations for the transportation of animals in Ukraine [11]. In addition, it is necessary to create special areas for short-term walking of animals along the route.

The threat of injury to animals can be reduced by observing the rules for transporting animals, as well as the use of special devices that restrict independent movement and their mobility in case of sudden jolts. 


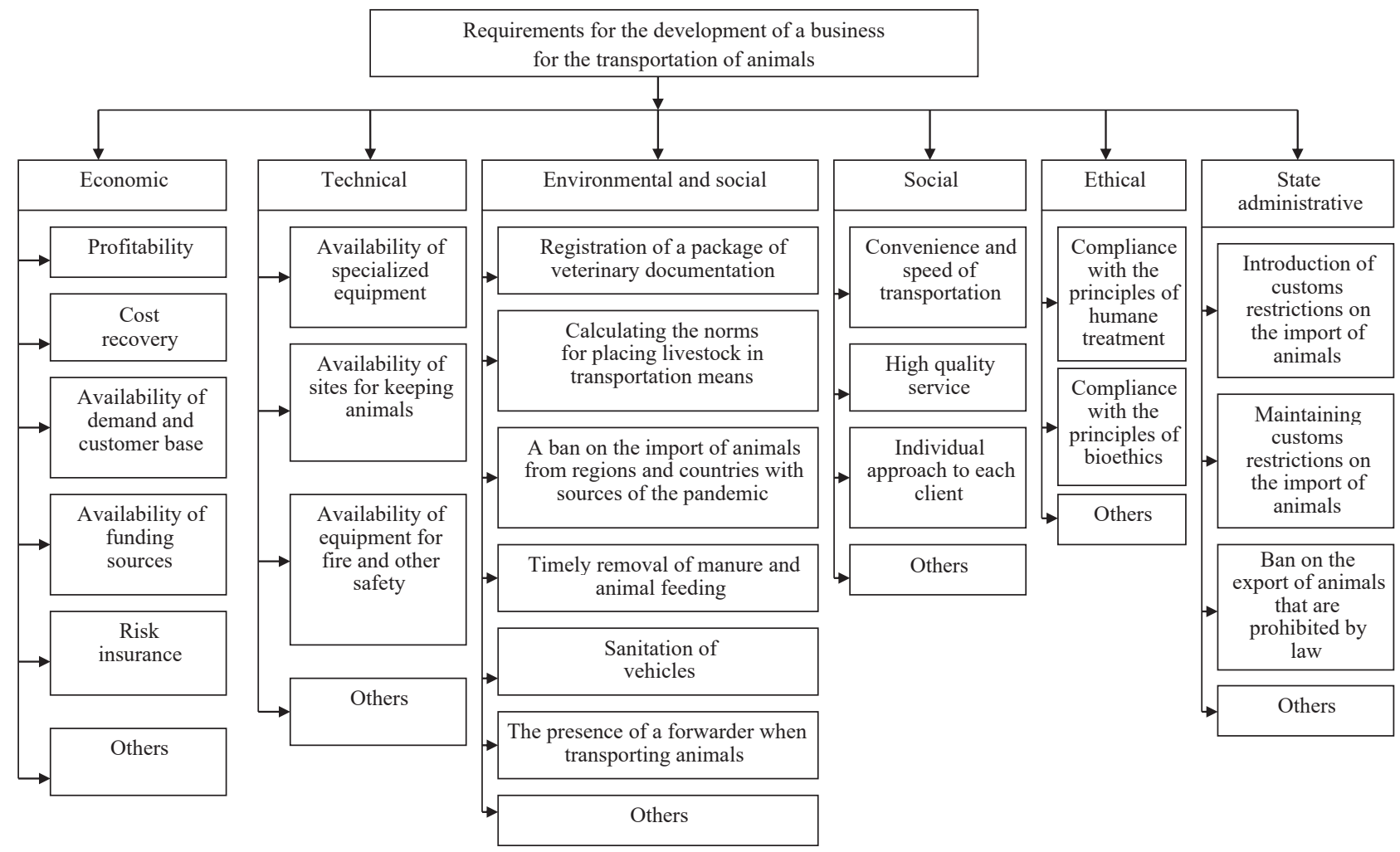

Fig. 2. Requirements for the development of a business for the transportation of animals (developed by the author)

Considerable attention is paid to the improvement of the ecological situation in the world. The impact of animals on the environment is associated with the pollution of rolling stock and places where animals are walking along the route with both garbage and waste. Therefore, when transporting animals, it is important to take into account environmental and sanitary rules, including the «Sanitary Code of Terrestrial Animals» of the International Epizootic Bureau (OIE) and the World Organization for Animal Health, as well as compliance with the norms for their placement in rolling stock [12]. Manure removal should only be carried out at designated locations. The rolling stock also requires cleaning and flushing of the body, including its internal equipment [13].

It is necessary to take into account the reverse effect of the environment on animals, which causes appropriate reactions on their part. So, certain environmental factors (temperature, humidity) can cause functional disorders of organs and systems, as well as the death of an animal.

Undoubtedly, the ethical standards defined by the European Convention for the Protection of Animals during International Transport (1968) and other rules of humane and responsible treatment of animals encourage adherence to the principles of veterinary bioethics. According to the laws of bioethics, which operate in developed countries, it is impossible to inflict pain, suffering, fear on animals. However, according to research by scientists in current practice, animals on the way to the slaughterhouse experience extreme stress, especially livestock that are transported from another continent. Fear due to an unusual environment, shaking, hypothermia or overheating, unloading by transport lead to deep stress in the animal. Unnatural conditions cause constant fear in the animal, from which it can die. This condition in pigs is called «porcine stress syndrome». To reduce its level, it is necessary to create for them such transportation conditions under which animals can travel in the same groups in the absence of other animals. As shown in a study [14], the risk of death of pigs increases if they are fed before the journey.

\section{Conclusions}

So, on the basis of the study, methodological approaches to the formation of a system for monitoring the movement of products of animal origin based on the creation of an information system for automated document management «Biosafety» are substantiated. It will ensure the traceability of the movement of pig products at all stages of the agri-food chain, will provide a qualitatively new level of information and communication technologies in the industry. The main purpose of creating this information system is to streamline the distribution channels, in particular, the activities of market infrastructure entities, in particular, pig breeding. And also the creation of an effective mechanism to prevent the appearance on the market of pig products that are hazardous to the health of the end consumer.

An integrated approach to the segment of animal transportation will solve the main problems of organizing business, in particular: reducing transportation costs, minimizing environmental impact and ensuring humane treatment of animals.

\section{References}

1. Demchak, I. M. (2017). Otsinka efektyvnosti funktsionuvannia subiektiv miasoproduktovoho pidkompleksu Ukrainy. Kyiv: NDI «Ukrahropromproduktyvnist», 92.

2. Gadisov, M. G. (2012). O skotnykh rynkakh, kak instrumente rynochnogo obrascheniya zhivogo skota. Voprosy strukturizatsii ekonomiki, 2, 35-40.

3. Shpychak, O. M., Svynous, I. V. (2008). Realizatsiya produktsiyi osobystymy selyans'kymy hospodarstvamy - vytraty, tsiny, efektyonist'. Kyiv: IAE, 320. 
4. Putting Meat on the Table: Industrial Farm Animal Production in America (2008). Report of the Pew Commission on Industrial Farm Animal Production. Available at: https://www. pewtrusts.org/ /media/legacy/uploadedfiles/peg/publications/ report/PCIFAPFINALpdf.pdf Last accessed: 12.12.2019

5. Svynous, I. V. (2017). Formuvannia informatsiino-konsultatyvnoho zabezpechennia funktsionuvannia subiektiv ahrarnoho rynku. Zbirnyk naukovykh prats Tavriiskoho derzhavnoho ahrotekhnolohichnoho universytetu (ekonomichni nauky), 1-2, 269-275.

6. Ibatullin, M. I. (2016). Organisational approaches to formation of the system of price monitoring on the market of pork products. Nauka y ekonomika, 2, 61-67.

7. Zasiekin, D. A., Poliakovskyi, V. M., Solomon, V. V. (2010) Transportuvannia tvaryn i produktsii (sanitarno-hihiienichni aspekty). Kyiv: Ahrar Media Hrup, 318.

8. The Transformation of U.S. Livestock Agriculture: Scale, Efficiency and Risks Service. EIB-43 Economic Research Service/ USDA. Available at: https://www.ers.usda.gov/webdocs/publications /44292/10992 eib43.pdf? v=0 Last accessed: 19.11.2019

9. Svynous, I. V., Varchenko, O. M. (2019). Ekonomichni aspekty rozoytku tvarynnytstva v osobystykh selianskykh hospodarstvakh. Bila Tserka: BNAU, 384.

10. Mazurenko, O. (2013). Orhanizatsiino-ekonomichni osoblyvosti mizhnarodnykh perevezen silskohospodarskykh tvaryn. Visnyk Lvivskoho natsionalnoho ahrarnoho universytetu. Seriia: Ekonomika APK, 20 (1), 306-314.

11. Pro zatverdzhennia Pravyl transportuvannia tvaryn (2011) Postanova Kabinetu Ministriv Ukrainy No. 1402. 16.11.2011. Available at: http://zakon5.rada.gov.ua/laws/show/1402-2011$\% \mathrm{D} 0 \% \mathrm{BF}$

12. The Common Agricultural Policy after 2013. Legal proposals for the CAP after 2013. European Commission, 2013. Available at: http://ec.europa.eu/agriculture/cap-post-2013/legal-proposals/ index_en.htm Last accessed: 23.08.2016.
13. Reglament Evropeiskogo Parlamenta i Soveta po veterinarnosa-nitarnym trebovaniyam, primenyaemym $k$ nekommercheskomu peremescheniyu domashnikh zhivotnykh (2003). 26.05,2003. Available at: http://zakon3.rada.gov.ua/laws/show/994 a67

14. Pavlova, E. I. (2010). Ekologiya transporta. Moscow: Vysshaya shkola, 307.

Olena Shust, Doctor of Economic Sciences, Professor, Rector Bila Tserkva National Agrarian University, Bila Tserkva, Ukraine, e-mail: bnau-rectorat@btsau.edu.ua,ORCID: https://orcid.org/00000001-7066-8020

Igor Paska, Doctor of Economic Sciences, Professor, Dean of the Faculty of Economics, Bila Tserkva National Agrarian University, Bila Tserkva, Ukraine, e-mail: paska.igor@ukr.net, ORCID: https:// orcid.org/0000-0003-4453-8905

Dmytro Krysanov, Doctor of Economic Sciences, Professor, Depart ment of Finance, Banking And Insurance, Bila Tserkva National Agrarian University, Bila Tserkva, Ukraine, e-mail: d krysanov@ukr.net, ORCID: https://orcid.org/0000-0002-9065-3325

Marat Ibatullin, Doctor of Economic Sciences, Associate Professor, Department of Administrative Management and Foreign Economic Activity, National University of Life and Environmental Sciences of Ukraine, Kyiv, Ukraine, e-mail: imi_1@ukr.net, ORCID: https:// orcid.org/0000-0001-8765-6261

Iryna Artimonova, PhD, Associate Professor, Department of Finance, Banking And Insurance, Bila Tserkva National Agrarian University, Bila Tserkva, Ukraine, e-mail: artimonovaira@ukr.net, ORCID: https://orcid.org/0000-0003-1054-1356 